\title{
EFIKASI HERBISIDA PARAKUAT UNTUK PENGENDALIAN GULMA PADA BUDIDAYA KELAPA SAWIT (Elaeis guineensis Jacq) TANAMAN BELUM MENGHASILKAN
}

\section{EFFECT OF PARAQUAT DICHLORIDE HERBICIDE TO CONTROL WEEDS ON IMMATURE OIL PALM PLANT (Elaeis guineensis Jacq)}

\author{
Jatmiko Umar Sidik $^{1}$, Dad Resiworo Jekti Sembodo ${ }^{2 *}$, Rusdi Evizal ${ }^{1}$ dan Hidayat Pujisiswanto ${ }^{2}$ \\ ${ }^{1}$ Jurusan Agroteknologi Fakultas Pertanian Universitas Lampung \\ ${ }^{2}$ Jurusan Agronomi Fakultas Pertanian Universitas Lampung \\ Jalan Prof. Soemantri Brojonegoro No. 1 Bandar Lampung 35145 \\ *Email :dadresiworo@yahoo.com
}

\begin{abstract}
Good plantation management is important to increase the productivity of immature oil palm plants, one of which is chemical weed control. This study aims to (1) determine the dosage of paraquat herbicide which is effective in controlling weeds in the area of immature oil palm plantations, (2) find out the differences in the composition of weed species on immature oil palm plates after application of the paraquat herbicide, (3) find out the phytotoxicity of paraquat herbicides in immature oil palm plants after the application of the paraquat dichloride herbicide. This research was carried out in the farmers' oil palm plantation in Jontor Village, Gayabaru District, Central Lampung Regency and Weed Laboratory of the Faculty of Agriculture, University of Lampung from November 2017 to February 2018. This research used a Randomized Block Design (RBD) with 4 replications and 6 treatments consisting dose of paraquat dichloride herbicide of $375 \mathrm{~g} / \mathrm{ha}, 500 \mathrm{~g} / \mathrm{ha}, 625 \mathrm{~g} / \mathrm{ha}, 750 \mathrm{~g} / \mathrm{ha}$, and mechanical weeding and without weed control (control). Homogeneity of the various data was tested by the Bartlett test, data additivity was tested by the Tukey test and the difference in the mean was tested with the Least Significant Difference (LSD) test at a 5 level. The result of the study showed that: (1) the herbicide paraquat dichloride dose of 375-750 $\mathrm{g} / \mathrm{ha}$ effectively control weeds in total, weed leaf width of up to 8 week after application, weed grasses and weeds puzzle to 4 week after application, (2) the herbicide paraquat dichloride dose of 375-750 $\mathrm{g} / \mathrm{h}$ a is effective in controlling Praxelis clematidea weeds up to 8 week after application, weed Ottochloa nodosa and Asystasia gangetica up to 4 week after application, (3) paraquate dichloride dosage levels 375-750 g / ha resulting in differences in weed composition at 4, 8 and 12 week after application , (4) dosages of 375 - $750 \mathrm{~g} / \mathrm{ha}$ parakuat dichloride herbicides applied to dishes not poisoning immature oil palm plants.
\end{abstract}

Keywords: Palm oil, weeds, paraquat dichloride herbicide 


\begin{abstract}
ABSTRAK
Pengelolaan perkebunan yang tepat dan efisien merupakan hal penting guna meningkatkan produktivitas kelapa sawit tanaman belum menghasilkan (TBM), salah satunya dengan pengendalian gulma secara kimiawi. Penelitian ini bertujuan untuk (1) mengetahui dosis herbisida parakuat yang efektif dalam mengendalikan gulma pada areal pertanaman kelapa sawit belum menghasilkan, (2) mengetahui perbedaan komposisi jenis gulma pada piringan kelapa sawit belum menghasilkan setelah aplikasi herbisida parakuat, (3) mengetahui fitotoksisitas herbisida parakuat pada tanaman kelapa sawit belum menghasilkan setelah aplikasi herbisida parakuat diklorida. Penelitian ini dilaksanakan di kebun kelapa sawit milik petani di Desa Jontor, Kecamatan Gayabaru, Kabupaten Lampung Tengah dan Laboratorium Gulma Fakultas Pertanian Universitas Lampung dari November 2017 hingga Februari 2018. Penelitan ini menggunakan Rancangan Acak Kelompok (RAK) dengan 4 ulangan dan 6 perlakuan yang terdiri dosis herbisida parakuat diklorida $375 \mathrm{~g} / \mathrm{ha}, 500 \mathrm{~g} / \mathrm{ha}, 625 \mathrm{~g} / \mathrm{ha}, 750 \mathrm{~g} / \mathrm{ha}$, penyiangan mekanis dan tanpa pengendalian gulma (kontrol). Homogenitas ragam data diuji dengan uji Bartlett, additivitas data diuji dengan uji Tukey dan perberbedaan nilai tengah diuji dengan uji Beda Nyata Terkecil (BNT) pada taraf á 5\% . Hasil penelitian menunjukkan bahwa: (1) herbisida parakuat diklorida dosis $375-750 \mathrm{~g} /$ ha efektif mengendalikan gulma total, gulma daun lebar sampai 8 MSA, gulma rumput dan gulma teki sampai 4 MSA, (2) herbisida parakuat diklorida dosis $375-750 \mathrm{~g}$ /ha efektif mengendalikan gulma Praxelis clematidea sampai 8 MSA, gulma Ottochloa nodosa dan Asystasia gangetica sampai 4 MSA, (3) herbisida parakuat diklorida taraf dosis $375-750 \mathrm{~g} /$ ha mengakibatkan terjadinya perbedaan komposisi gulma pada 4, 8, dan $12 \mathrm{MSA}$, (4) dosis herbisida parakuat diklorida 375 - $750 \mathrm{~g}$ /ha yang diaplikasikan pada piringan tidak meracuni tanaman kelapa sawit belum menghasilkan.
\end{abstract}

Kata Kunci : Kelapa sawit, gulma, herbisida parakuat diklorida.

\section{PENDAHULUAN}

Dalam budidaya kelapa sawit terdapat kendala yang dapat menghambat pertumbuhan tanaman kelapa sawit yang dibudidayakan. Salah satu kendala yang dapat menghambat pertumbuhan kelapa sawit adalah gulma. Perkebunan kelapa sawit TBM menghadapi masalah gulma yang tinggi karena jarak tanam yang lebih lebar sehingga penutupan tanah olehkanopi lambat dan membuat cahaya matahari leluasa mencapai permukaan tanah yang kaya dengan potensi gulma (Hakim, 2007). Tanaman TBM membutuhkan pemeliharaan yang optimal untuk mencapai produksi maksimal pada fase TM. Menurut Setyawibawa dan
Widyastuti (1999), keberadaan gulma di lahan perkebunan kelapa sawit dapat menghambat dan menurunkan produksi sebesar $15-20 \%$.

Teknik pengendalian gulma yang umum digunakan adalah dengan cara manual dan kimiawi. Pengendalian secara manual membutuhkan tenaga kerja yang banyak dan waktu yang cukup lama. Artinya, pengendalian secara manual memerlukan biaya yang jauh lebih mahal jika dibandingkan dengan pengendalian secara kimiawi (Tjitrosoedirdjo dkk., 1984). Parakuat diklorida (1,1"dimethyl, 4,4"bipyridylium) merupakan suatu herbisida golongan bipyridylium. Herbisida yang termasuk dalam golongan 
ini umumnya merupakan herbisida pasca tumbuh, tidak aktifapabila diaplikasikan lewat tanah dan bersifat tidak selektif(Suntres, 2002).

Hasil penelitian yang telah dilakukan oleh Murti dkk., (2016) menunjukkan bahwa herbisida parakuat diklorida dengan dosis $414 \mathrm{~g} / \mathrm{ha}-966 \mathrm{~g} / \mathrm{ha}$ mampu menekan pertumbuhan gulma total ubi kayu sampai 8 minggu setelah aplikasi (MSA) serta mampu mengendalikan gulma golongan daun lebar Ipomoea triloba dan Richardia brasiliensis hingga 8 MSA serta aplikasi herbisida parakuat diklorida pada lahan tidak meracuni tanaman ubi kayu.

Penelitian ini bertujuan untuk mengetahui dosis herbisida parakuat yang efektif dalam mengendalikan gulma pada areal pertanaman kelapa sawit belum menghasilkan, mengetahui perbedaan komposisi jenis gulma pada piringan tanaman kelapa sawit belum menghasilkan setelah aplikasi herbisida parakuat, dan mengetahui fitotoksisitas herbisida parakuat pada tanaman kelapa sawit belum menghasilkan setelah aplikasi.

\section{BAHAN DAN METODE}

Penelitian ini dilaksanakan di kebun kelapa sawit milik petani di Desa Jontor, Kecamatan Gayabaru, Kabupaten Lampung Tengah dari November 2017 hingga Februari 2018. Penelitan ini menggunakan Rancangan Acak Kelompok (RAK) dengan 4 ulangan dan 6 perlakuan yang terdiri dosis herbisida parakuat diklorida 375g/ha(P1), $500 \mathrm{~g} / \mathrm{ha}(\mathrm{P} 2), 625 \mathrm{~g} / \mathrm{ha}(\mathrm{P} 3)$, $750 \mathrm{~g} / \mathrm{ha}$ (P4), penyiangan mekanis (P5) dan kontrol (P6). Pengelompokan dilakukan berdasarkan keseragaman gulma yang ada pada petak percobaan. Untuk menguji homogenitas ragam data digunakan uji Bartlett dan additivitas data diuji dengan menggunakan uji Tukey. Jika asumsi terpenuhi, maka data dianalisis dengan sidik ragam dan untuk menguji perbedaan nilai tengah perlakuan diuji dengan uji Beda Nyata Terkecil (BNT) pada tarafá 5\%. Setiap satuan percobaan terdiri atas 3 tanaman kelapa sawit dengan jari-jari piringan 3 meter. Petak lahan yang digunakan kondisi penutupan gulma $>75 \%$. Volume semprot yang diperoleh dari hasil kalibrasi yaitu 530 1/ha dan diaplikasikan dengan menggunakan knapsack sprayer semi automatic dengan nozzel berwarna biru.

Pengambilan gulma dilakukan sebanyak tiga kali, yaitu saat 4, 8, dan 12 minggu setelah aplikasi (MSA) dengan menggunakan kuadran berukuran $0.5 \mathrm{~m}$ $\mathrm{x} 0.5 \mathrm{~m}$ pada piringan kelapa sawit. Selanjutnya gulma dipilih sesuai spesiesnya dan dioven dengan suhu $80^{\circ} \mathrm{C}$ selama 48 jam hingga bobot kering konstan lalu ditimbang. Nilai Summed Dominance Ratio (SDR) dihitung setelah didapatkan bobot kering gulma untuk menentukan urutan gulma dominan yang ada di lahan. Persen penekanan herbisida terhadap gulma diperoleh dari data bobot kering gulma total, pergolongan, dan dominan. Nilai C menunjukkan kesamaan komposisi gulma antar perlakuan yang dibandingkan. Rumus koefisien komunitas adalah :

$$
\mathrm{C}=\frac{2 \times W}{a+b} \times 100 \%
$$

Keterangan :

$\mathrm{C}=$ Koefisien komunitas

$\mathrm{W}=$ Jumlah nilai terendah dari pasangan SDR pada dua komunitas yang dibandingkan 
a $\quad=$ Jumlah semua SDR dari komunitas I

$\mathrm{b}=$ Jumlah semua SDR dari komunitas II

Jika nilai C $>75 \%$ maka dua komunitas yang dibandingkan memiliki komposisi gulma yang sama (Tjitrosoedirjo dkk., 1984).

\section{HASIL DAN PEMBAHASAN}

\section{Bobot Kering Gulma Total}

Hasil penelitian (Tabel 1) menunjukkan bahwa herbisida parakuat diklorida pada dosis $375-750 \mathrm{~g} /$ ha mampu mengendalikan gulma total dibanding kontrol pada piringan kelapa sawit belum menghasilkan (TBM) sampai dengan 8 MSA. Hal tersebut dikarenakan herbisida parakuat diklorida merupakan herbsida kontak sehingga gulma pada piringan kelapa sawit yang diaplikasikan sudah pulih kembali. Sesuai dengan Sembodo (2010), kelemahan herbisida parakuat adalah gulma akan tumbuh kembali secara cepat sekitar 2 sampai 3 minggu kemudian. Pada pengamatan 4 dan 8 MSA, taraf dosis $375-750 \mathrm{~g} /$ ha herbisida parakuat diklorida efektif mengendalikan gulma total pada piringan kelapa sawit. Hal serupa juga terjadi pada peyiangan mekanis pengamatan 4 dan 8 MSA yang mampu mengendalikan gulma total. Pada 12 MSA, dosis $375 \mathrm{~g} /$ ha dan $500 \mathrm{~g} /$ ha mampu mengendalikan gulma total pada piringan kelapa sawit. Sementara itu, taraf dosis $625 \mathrm{~g} / \mathrm{ha}, 750 \mathrm{~g} / \mathrm{ha}$ dan penyiangan mekanis tidak efektifmengendalikan gulma total.

\section{Bobot Kering Gulma Golongan Daun Lebar}

Tabel 2 menunjukkan bahwa pada 4 MSA herbisida parakuat diklorida dosis $375-750 \mathrm{~g}$ /ha efektif mengendalikan gulma golongan daun lebar. Hal serupa ditunjukkan juga pada pengendalian mekanis yang mampu mengendalikan gulma golongan daun lebar. Seluruh taraf dosis herbisida parakuat diklorida dan penyiangan mekanis efektifdalam mengendalikan gulma daun lebar pada 4 MSA. Taraf dosis $375-750 \mathrm{~g} / \mathrm{ha}$ herbisida parakuat diklorida dan penyiangan mekanis pada 8 MSA mampu menekan pertumbuhan gulma golongan daun lebar. Pada 12 MSA herbisida parakuat diklorida dengan dosis $625,750 \mathrm{~g} /$ ha dan pengendalian mekanis tidak mampumengendalikan gulma daun lebar.

Tabel 1. Pengaruh perlakuan herbisida parakuat diklorida terhadap bobot kering gulma total

\begin{tabular}{|c|c|c|c|c|c|c|}
\hline \multirow[b]{2}{*}{ Perlakuan } & \multicolumn{2}{|c|}{4 MSA } & \multicolumn{2}{|c|}{$8 \mathrm{MSA}$} & \multicolumn{2}{|c|}{12 MSA } \\
\hline & $\begin{array}{c}\text { Data } \\
\text { Asli } \\
\end{array}$ & $\begin{array}{c}\sqrt{ } \sqrt{ } \\
(\mathrm{x}+0.5) \\
\end{array}$ & $\begin{array}{r}\text { Data } \\
\text { Asli } \\
\end{array}$ & $\begin{array}{c}\sqrt{ } \\
(x+0.5) \\
\end{array}$ & $\begin{array}{c}\text { Data } \\
\text { Asli } \\
\end{array}$ & $\begin{array}{c}\sqrt{ } \\
(x+0.5) \\
\end{array}$ \\
\hline & & & .....(g) & $\left.n^{2}\right)$. & & \\
\hline Parakuat diklorida $375 \mathrm{~g} / \mathrm{ha}$ & 2.83 & $1.32 \mathrm{bc}$ & 22.17 & $4.72 \mathrm{~b}$ & 27.68 & $5.23 \mathrm{bc}$ \\
\hline Parakuat diklorida $500 \mathrm{~g} / \mathrm{ha}$ & 2.26 & $1.19 \mathrm{c}$ & 26.29 & $5.08 \mathrm{~b}$ & 25.66 & $5.08 \mathrm{c}$ \\
\hline Parakuat diklorida $625 \mathrm{~g} / \mathrm{ha}$ & 3.58 & $1.37 \mathrm{bc}$ & 26.24 & $5.15 \mathrm{~b}$ & 55.26 & $7.18 \mathrm{ab}$ \\
\hline Parakuat diklorida $750 \mathrm{~g} / \mathrm{ha}$ & 5.57 & $1.53 \mathrm{~b}$ & 22.29 & $4.71 \mathrm{~b}$ & 67.42 & $8.18 \mathrm{a}$ \\
\hline Mekanis & 2.39 & $1.26 \mathrm{bc}$ & 18.47 & $4.32 \mathrm{~b}$ & 62.32 & $7.87 \mathrm{a}$ \\
\hline Kontrol & 52.47 & $2.81 \mathrm{a}$ & 58.43 & $7.58 \mathrm{a}$ & 59.35 & $7.71 \mathrm{a}$ \\
\hline BNT 5\% & & 0.33 & & 1.12 & & 1.95 \\
\hline
\end{tabular}

Keterangan : Nilai tengah pada setiap kolom yang diikuti huruf yang sama tidak berbeda nyata menurut uji BNT pada taraf 5\%. 
Tabel 2. Pengaruh perlakuan herbisida parakuat diklorida terhadap bobot kering gulma golongan daun lebar

\begin{tabular}{|c|c|c|c|c|c|c|}
\hline \multirow[b]{2}{*}{ Perlakuan } & \multicolumn{2}{|c|}{$4 \mathrm{MSA}$} & \multicolumn{2}{|c|}{8 MSA } & \multicolumn{2}{|c|}{$12 \mathrm{MSA}$} \\
\hline & $\begin{array}{l}\text { Data } \\
\text { Asli }\end{array}$ & $\begin{array}{c}\sqrt{ } \\
(x+0.5)\end{array}$ & $\begin{array}{l}\text { Data } \\
\text { Asli }\end{array}$ & $\begin{array}{c}\sqrt{ } \\
(\mathrm{x}+0.5)\end{array}$ & $\begin{array}{l}\text { Data } \\
\text { Asli }\end{array}$ & $\begin{array}{c}\sqrt{ } \\
(x+0.5)\end{array}$ \\
\hline & & & $\ldots .(g$ & $\left.\mathrm{m}^{2}\right)$. & & \\
\hline Parakuat diklorida $375 \mathrm{~g} / \mathrm{ha}$ & 1.95 & $1.25 \mathrm{~b}$ & 22.17 & $4.72 \mathrm{~b}$ & 25.46 & $5.00 \mathrm{~cd}$ \\
\hline Parakuat diklorida $500 \mathrm{~g} /$ ha & 0.78 & $1.02 \mathrm{bc}$ & 25.32 & $4.98 \mathrm{~b}$ & 23.69 & $4.88 \mathrm{~d}$ \\
\hline Parakuat diklorida $625 \mathrm{~g} / \mathrm{ha}$ & 0.55 & $0.98 \mathrm{c}$ & 16.03 & $4.00 \mathrm{~b}$ & 32.46 & $5.72 \mathrm{bcd}$ \\
\hline Parakuat diklorida $750 \mathrm{~g} /$ ha & 0.67 & $1.01 \mathrm{bc}$ & 19.00 & $4.38 \mathrm{~b}$ & 37.87 & $6.18 \mathrm{abc}$ \\
\hline Mekanis & 2.04 & $1.23 \mathrm{bc}$ & 16.81 & $4.11 \mathrm{~b}$ & 55.05 & $7.41 \mathrm{a}$ \\
\hline Kontrol & 16.69 & $2.01 \mathrm{a}$ & 43.58 & $6.63 \mathrm{a}$ & 43.98 & $6.59 \mathrm{ab}$ \\
\hline BNT 5\% & & 0.26 & & 1.18 & & 1.27 \\
\hline
\end{tabular}

Keterangan : Nilai tengah pada setiap kolom yang diikuti huruf yang sama tidak berbeda nyata menurut uji BNT pada taraf 5\%.

Tabel 3. Pengaruh perlakuan herbisida parakuat dilorida terhadap bobot kering gulma golongan rumput

\begin{tabular}{|c|c|c|c|c|c|c|}
\hline \multirow[b]{2}{*}{ Perlakuan } & \multicolumn{2}{|c|}{$4 \mathrm{MSA}$} & \multicolumn{2}{|c|}{$8 \mathrm{MSA}$} & \multicolumn{2}{|c|}{$12 \mathrm{MSA}$} \\
\hline & $\begin{array}{l}\text { Data } \\
\text { Asli }\end{array}$ & $\begin{array}{c}\sqrt{ } \sqrt{ } \\
(\mathrm{x}+0.5)\end{array}$ & $\begin{array}{r}\text { Data } \\
\text { Asli }\end{array}$ & $\begin{array}{c}\sqrt{ } \sqrt{ } \\
(\mathrm{x}+0.5)\end{array}$ & $\begin{array}{l}\text { Data } \\
\text { Asli }\end{array}$ & $\begin{array}{c}\sqrt{ } \sqrt{ } \\
(x+0.5)\end{array}$ \\
\hline & & r & & $\left.5 \mathrm{~m}^{2}\right) \ldots$. & & \\
\hline Parakuat diklorida $375 \mathrm{~g} / \mathrm{ha}$ & 0.88 & $1.03 \mathrm{~cd}$ & 0.00 & $0.92 \mathrm{c}$ & 1.67 & $1.16 \mathrm{~b}$ \\
\hline Parakuat diklorida $500 \mathrm{~g} / \mathrm{ha}$ & 1.49 & $1.04 \mathrm{~cd}$ & 0.83 & $1.02 \mathrm{c}$ & 1.98 & $1.16 \mathrm{~b}$ \\
\hline Parakuat diklorida $625 \mathrm{~g} / \mathrm{ha}$ & 3.03 & $1.32 \mathrm{bc}$ & 10.21 & $1.27 \mathrm{ab}$ & 22.81 & $1.40 \mathrm{ab}$ \\
\hline Parakuat diklorida $750 \mathrm{~g} / \mathrm{ha}$ & 4.79 & $1.49 \mathrm{~b}$ & 3.29 & $1.12 \mathrm{abc}$ & 29.56 & $1.51 \mathrm{a}$ \\
\hline Mekanis & 0.35 & $0.90 \mathrm{~d}$ & 1.42 & $1.05 \mathrm{bc}$ & 7.13 & $1.29 \mathrm{ab}$ \\
\hline Kontrol & 35.67 & $2.54 \mathrm{a}$ & 14.22 & $1.30 \mathrm{a}$ & 13.67 & $1.42 \mathrm{ab}$ \\
\hline BNT 5\% & & 0.4 & & 0.22 & & 0.27 \\
\hline
\end{tabular}

Keterangan : Nilai tengah pada setiap kolom yang diikuti huruf yang sama tidak berbeda nyata menurut uji BNT pada taraf $5 \%$.

Sedangkan dosis $375 \mathrm{~g} /$ ha dan $500 \mathrm{~g} /$ ha menunjukkan bahwa dosis tersebut mampu mengendalikan gulma daun lebar dan hal tersebut menunjukkan efektifitas herbisida parakuat diklorida dalam menekan pertumbuhan gulma daun lebar.

\section{Bobot Kering Gulma Golongan Rumput}

Terdapat 5 spesies gulma golongan rumput pada petak percobaan yaitu Axonopus compresus, Paspalum comersonii, Ottochloa nodosa, Paspalum conjugatum, Digitaria ciliaris. Hasil penelitian (Tabel 3) menunjukkan bahwa herbisisda parakuat diklorida dosis $375-750 \mathrm{~g} / \mathrm{ha}$ dan penyiangan mekanis efektif mengendalikan gulma golongan rumput pada 4 MSA.
Taraf dosis $375 \mathrm{~g} /$ ha dan $500 \mathrm{~g} /$ ha memiliki daya kendali yang tidak berbeda dengan penyiangan mekanis. Hal yang serupa juga ditunjukkan pada taraf dosis $625 \mathrm{~g} /$ ha dan $750 \mathrm{~g} /$ ha yang memiliki daya kendali yang tidak berbeda. Pada 8 MSA, taraf dosis $375 \mathrm{~g} / \mathrm{ha}, 500 \mathrm{~g} / \mathrm{ha}$ dan penyiangan mekanis efektif mengendalikan pertumbuhan gulma rumput. Sedangkan pada taraf dosis $625 \mathrm{~g} / \mathrm{ha}$ dan $750 \mathrm{~g} / \mathrm{ha}$ tidak mampu mengendalikan gulma rumput. Pada pengamatan 12 MSA, seluruh taraf dosis herbisida parakuat diklorida dan penyiangan mekanis tidak mampu menekan pertumbuhan gulma rumput. 


\section{Bobot Kering Gulma Golongan Teki}

Terdapat 2 spesies gulma golongan teki yaitu Cyperus kyllingia dan Cyperus iria. Hasil penelitian (Tabel 4) pada pengamatan 4 MSA menunjukkan bahwa seluruh taraf dosis ( $375-750 \mathrm{~g} / \mathrm{ha}$ ) herbisida parakuat diklorida efektif dalam mengendalikan gulma golongan teki. Penyiangan mekanis juga efektif mengendalikan gulma. Sementara itu pada 8 dan 12 MSA, herbisida parakuat diklorida disemua taraf dosis yang diuji tidak mampu mengendalikan gulma teki. Hal yang mengakibatkan tidak terkendalinya gulma teki ini adalah komunitas jenis gulma teki tertutup oleh dominasi gulma golongan daun lebar dan rumput. Menurut
Sukman dan Yakup (2002), herbisida parakuat kurang efektif dalam mematikan gulma yang memiliki akar rimpang atau stolon.

\section{Bobot Kering Gulma Ottochloa nodosa}

Hasil penelitian pada Tabel 5 menunjukkan bahwa gulma $O$. nodosa dapat dikendalikan dengan efektif oleh herbisida parakuat diklorida pada taraf dosis $375-750 \mathrm{~g} / \mathrm{ha}$ dan perlakuan penyiangan mekanis di pengamatan 4 MSA. Pada 8 dan 12 MSA, taraf dosis 375 - $750 \mathrm{~g}$ /ha herbisida parakuat diklorida tidak efektifmengendalikan pertumbuhan gulma

O. nodosa. Pada penyiangan mekanis pun tidak mampu mengendalikan gulma $O$. nodosa di

Tabel 4. Pengaruh perlakuan herbisida parakuat diklorida terhadap bobot kering gulma golongan teki

\begin{tabular}{|c|c|c|c|c|c|c|}
\hline \multirow[b]{2}{*}{ Perlakuan } & \multicolumn{2}{|c|}{$4 \mathrm{MSA}$} & \multicolumn{2}{|c|}{$8 \mathrm{MSA}$} & \multicolumn{2}{|c|}{$12 \mathrm{MSA}$} \\
\hline & $\begin{array}{r}\text { Data } \\
\text { Asli } \\
\end{array}$ & $\begin{array}{c}\sqrt{ } \\
(x+0.5) \\
\end{array}$ & $\begin{array}{r}\text { Data } \\
\text { Asli } \\
\end{array}$ & $\begin{array}{c}\sqrt{ } \\
(\mathrm{x}+0.5) \\
\end{array}$ & $\begin{array}{r}\text { Data } \\
\text { Asli } \\
\end{array}$ & $\begin{array}{c}\sqrt{ } \sqrt{ } \\
(\mathrm{x}+0.5)\end{array}$ \\
\hline & & & & $\left.5 \mathrm{~m}^{2}\right) \ldots \ldots \ldots$ & & \\
\hline Parakuat diklorida $375 \mathrm{~g} / \mathrm{ha}$ & 0.00 & $0.71 \mathrm{~b}$ & 0.00 & $0.71 \mathrm{a}$ & 0.56 & $1.19 \mathrm{a}$ \\
\hline Parakuat diklorida $500 \mathrm{~g} / \mathrm{ha}$ & 0.00 & $0.71 \mathrm{~b}$ & 0.00 & $0.79 \mathrm{a}$ & 0.00 & $1.10 \mathrm{a}$ \\
\hline Parakuat diklorida $625 \mathrm{~g} / \mathrm{ha}$ & 0.00 & $0.71 \mathrm{~b}$ & 0.00 & $0.71 \mathrm{a}$ & 0.00 & $1.10 \mathrm{a}$ \\
\hline Parakuat diklorida $750 \mathrm{~g} / \mathrm{ha}$ & 0.11 & $0.71 \mathrm{~b}$ & 0.00 & $0.71 \mathrm{a}$ & 0.00 & $1.10 \mathrm{a}$ \\
\hline Mekanis & 0.00 & $0.71 \mathrm{~b}$ & 0.24 & $0.83 \mathrm{a}$ & 0.15 & $1.13 \mathrm{a}$ \\
\hline Kontrol & 0.08 & $0.79 \mathrm{a}$ & 0.64 & $0.77 \mathrm{a}$ & 1.70 & $1.30 \mathrm{a}$ \\
\hline BNT 5\% & & 0.05 & & 0.19 & & 0.23 \\
\hline
\end{tabular}

Keterangan : Nilai tengah pada setiap kolom yang diikuti huruf yang sama tidak berbeda nyata menurut uji BNT pada taraf $5 \%$.

Tabel 5. Pengaruh perlakuan herbisida parakuat diklorida terhadap bobot kering gulma dominan $O$. nodosa

\begin{tabular}{|c|c|c|c|c|c|c|}
\hline \multirow[b]{2}{*}{ Perlakuan } & \multicolumn{2}{|l|}{$4 \mathrm{MSA}$} & \multicolumn{2}{|l|}{$8 \mathrm{MSA}$} & \multicolumn{2}{|c|}{$12 \mathrm{MSA}$} \\
\hline & $\begin{array}{l}\text { Data } \\
\text { Asli }\end{array}$ & $\begin{array}{r}\sqrt{ } \sqrt{ } \\
(\mathrm{x}+0.5) \\
\end{array}$ & $\begin{array}{l}\text { Data } \\
\text { Asli }\end{array}$ & $\begin{array}{c}\sqrt{ } \sqrt{ } \\
(\mathrm{x}+0.5) \\
\end{array}$ & $\begin{array}{l}\text { Data } \\
\text { Asli }\end{array}$ & $\begin{array}{c}\sqrt{ } \sqrt{ } \\
(\mathrm{x}+0.5)\end{array}$ \\
\hline & & & $\ldots . . .(\mathrm{g})$ & 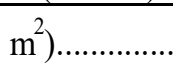 & & \\
\hline Parakuat diklorida $375 \mathrm{~g} / \mathrm{ha}$ & 0.67 & $0.97 \mathrm{~b}$ & 0.00 & $0.92 \mathrm{~b}$ & 0.00 & $1.26 \mathrm{~b}$ \\
\hline Parakuat diklorida $500 \mathrm{~g} / \mathrm{ha}$ & 1.44 & $1.03 \mathrm{~b}$ & 0.41 & $0.92 \mathrm{~b}$ & 0.00 & $1.26 \mathrm{~b}$ \\
\hline Parakuat diklorida $625 \mathrm{~g} / \mathrm{ha}$ & 0.98 & $1.02 \mathrm{~b}$ & 9.48 & $1.26 \mathrm{a}$ & 22.31 & $1.53 \mathrm{a}$ \\
\hline Parakuat diklorida $750 \mathrm{~g} / \mathrm{ha}$ & 3.84 & $1.25 \mathrm{~b}$ & 1.10 & $1.02 \mathrm{~b}$ & 27.98 & $1.62 \mathrm{a}$ \\
\hline Mekanis & 0.00 & $0.84 \mathrm{~b}$ & 1.13 & $1.01 \mathrm{~b}$ & 5.33 & $1.42 \mathrm{ab}$ \\
\hline Kontrol & 23.33 & $2.30 \mathrm{a}$ & 7.41 & $1.15 \mathrm{ab}$ & 9.11 & $1.50 \mathrm{ab}$ \\
\hline BNT 5\% & & 0.46 & & 0.24 & & 0.26 \\
\hline
\end{tabular}

Keterangan : Nilai tengah pada setiap kolom yang diikuti huruf yang sama tidak berbeda nyata menurut uji BNT pada taraf 5\%. 
piringan kelapa sawit.

\section{Bobot Kering Gulma Praxelis clematidea}

Hasil penelitian pada Tabel 6 menunjukkan bahwa herbisida parakuat diklorida taraf dosis $375-$ $750 \mathrm{~g} /$ ha efektif mengendalikan gulma $P$. clematidea pada 4 MSA. Begitu juga pada perlakuan penyiangan mekanis mampu mengendalikan pertumbuhan gulma $P$. clematidea pada piringan kelapa sawit TBM. Pada 8 MSA, taraf dosis $500-750 \mathrm{~g} / \mathrm{ha}$ dan penyiangan mekanis menunjukkan bahwa herbisida parakuat diklorida mampu mengendalikan pertumbuhan gulma P. clematidea. Sedangkan pada taraf dosis $375 \mathrm{~g} / \mathrm{ha}$ herbisida parakuat diklorida tidak mampu mengendalikan gulma Praxelis clematidea di piringan kelapa sawit. Pada 12 MSA herbisida parakuat diklorida taraf dosis 375 - $635 \mathrm{~g} /$ ha dan penyiangan mekanis tidak mampu mengendalikan gulma $P$. clematidea. Tidak terkendalinya P. clematidea diduga karena gulma baru mulai tumbuh kembali. Hal ini serupa dengan penelitian Riry (2006), bahwa lahan yang diaplikasikan dengan herbisida pasca tumbuh jenis parakuat diklorida akan didominasi oleh jenis daun lebar dan rumput-rumputan.

\section{Bobot Kering Gulma Asytasia gangetica}

Hasil pengamatan yang ditunjukkan pada Tabel 7 menyatakan bahwa pada 4 MSA herbisida parakuat diklorida dosis $500-750 \mathrm{~g} /$ ha efektif mengendalikan gulma $A$. gangetica. Sedangkan pada taraf dosis 375 g/ha tidak efektif mengendalikan gulma. Pada 8 MSA, taraf dosis 500-750 g/h tidak mampu mengendalikan gulma. Berbeda dengan taraf dosis $375 \mathrm{~g} / \mathrm{ha} \mathrm{mampu}$ mengendalikan gulma $A$. gangetica yang ditunjukkan dengan daya kendali yang lebih tinggi. Pada pengamatan $12 \mathrm{MSA}$, taraf dosis $500,750 \mathrm{~g} / \mathrm{ha}$ dan penyiangan mekanis efektif mengendalikan gulma $A$. gangetica di piringan kelapa sawit TBM. Sementara itu, taraf dosis $375 \mathrm{~g} / \mathrm{ha}$ dan $625 \mathrm{~g} /$ ha tidak mampu mengendalikan gulma A. gangetica di piringan kelapa sawit TBM.

\section{Perbedaan Komposisi Gulma}

Data pada Tabel 8 menunjukkan bahwa petak percobaan herbisida parakuat diklorida memiliki perbedaan komposisi gulma dengan nilai sebesar 23 $79 \%$. Hanya petak percobaan pada dosis $500 \mathrm{~g} / \mathrm{ha}$ dan kontrol yang menunjukkan perbedaan komposisi

Tabel 6. Pengaruh perlakuan herbisida parakuat diklorida terhadap bobot kering gulma dominan P. clematidea

\begin{tabular}{|c|c|c|c|c|c|c|}
\hline \multirow{3}{*}{ Perlakuan } & \multicolumn{2}{|c|}{$4 \mathrm{MSA}$} & \multicolumn{2}{|c|}{$8 \mathrm{MSA}$} & \multicolumn{2}{|c|}{$12 \mathrm{MSA}$} \\
\hline & Data & $\sqrt{ } \sqrt{ }$ & Data & $\sqrt{ }$ & Data & $\sqrt{ }$ \\
\hline & Asli & $(x+0.5)$ & Asli & $(x+0.5)$ & Asli & $(x+0.5)$ \\
\hline & \multicolumn{6}{|c|}{$\ldots \ldots \ldots\left(\mathrm{g} / 0.75 \mathrm{~m}^{2}\right) \ldots \ldots \ldots \ldots$} \\
\hline Parakuat diklorida $375 \mathrm{~g} / \mathrm{ha}$ & 0.02 & $0.85 \mathrm{~b}$ & 21.45 & $4.63 \mathrm{ab}$ & 20.98 & $4.51 \mathrm{ab}$ \\
\hline Parakuat diklorida $500 \mathrm{~g} / \mathrm{ha}$ & 0.17 & $0.89 \mathrm{~b}$ & 9.51 & $3.11 \mathrm{c}$ & 16.75 & $4.07 \mathrm{~b}$ \\
\hline Parakuat diklorida $625 \mathrm{~g} / \mathrm{ha}$ & 0.02 & $0.85 \mathrm{~b}$ & 10.97 & $3.28 \mathrm{c}$ & 24.70 & $5.01 \mathrm{ab}$ \\
\hline Parakuat diklorida $750 \mathrm{~g} / \mathrm{ha}$ & 0.00 & $0.84 \mathrm{~b}$ & 14.51 & $3.80 \mathrm{bc}$ & 36.15 & $6.03 \mathrm{a}$ \\
\hline Mekanis & 0.00 & $1.04 \mathrm{~b}$ & 11.00 & $3.33 \mathrm{c}$ & 24.84 & $4.97 \mathrm{ab}$ \\
\hline Kontrol & 7.98 & $1.61 \mathrm{a}$ & 31.09 & $5.60 \mathrm{a}$ & 17.77 & $4.09 \mathrm{~b}$ \\
\hline BNT 5\% & \multicolumn{2}{|r|}{0.25} & \multicolumn{2}{|r|}{1.11} & \multicolumn{2}{|r|}{1.59} \\
\hline
\end{tabular}

Keterangan : Nilai tengah pada setiap kolom yang diikuti huruf yang sama tidak berbeda nyata menurut uji BNT pada taraf $5 \%$. 
Tabel 7. Pengaruh perlakuan herbisida parakuat diklorida terhadap bobot kering gulma dominan A. gangetica

\begin{tabular}{|c|c|c|c|c|c|c|}
\hline \multirow[b]{2}{*}{ Perlakuan } & \multicolumn{2}{|c|}{$4 \mathrm{MSA}$} & \multicolumn{2}{|c|}{8 MSA } & \multicolumn{2}{|c|}{$12 \mathrm{MSA}$} \\
\hline & $\begin{array}{l}\text { Data } \\
\text { Asli } \\
\end{array}$ & $\begin{array}{c}\sqrt{ } \sqrt{ } \\
(\mathrm{x}+0.5) \\
\end{array}$ & $\begin{array}{l}\text { Data } \\
\text { Asli } \\
\end{array}$ & $\begin{array}{c}\sqrt{ } \\
(\mathrm{x}+0.5) \\
\end{array}$ & $\begin{array}{l}\text { Data } \\
\text { Asli } \\
\end{array}$ & $\begin{array}{c}\sqrt{ } \sqrt{ } \\
(\mathrm{x}+0.5) \\
\end{array}$ \\
\hline & & ........... & ....... ( & $\left.\mathrm{m}^{2}\right) \ldots$ & ....... & \\
\hline Parakuat diklorida $375 \mathrm{~g} / \mathrm{ha}$ & 1.67 & $1.20 \mathrm{ab}$ & 0.72 & $1.03 \mathrm{~b}$ & 3.50 & $1.25 \mathrm{ab}$ \\
\hline Parakuat diklorida $500 \mathrm{~g} / \mathrm{ha}$ & 0.57 & $0.98 \mathrm{bc}$ & 12.40 & $1.82 \mathrm{a}$ & 0.64 & $1.11 \mathrm{~b}$ \\
\hline Parakuat diklorida $625 \mathrm{~g} / \mathrm{ha}$ & 0.54 & $0.99 \mathrm{bc}$ & 4.86 & $1.51 \mathrm{a}$ & 4.82 & $1.21 \mathrm{ab}$ \\
\hline Parakuat diklorida $750 \mathrm{~g} / \mathrm{ha}$ & 0.12 & $0.88 \mathrm{c}$ & 4.49 & $1.49 \mathrm{a}$ & 0.00 & $1.05 \mathrm{~b}$ \\
\hline Mekanis & 0.69 & $1.00 \mathrm{bc}$ & 5.82 & $1.57 \mathrm{a}$ & 1.72 & $1.12 \mathrm{~b}$ \\
\hline Kontrol & 6.20 & $1.49 \mathrm{a}$ & 8.64 & $1.59 \mathrm{a}$ & 14.06 & $1.36 \mathrm{a}$ \\
\hline BNT 5\% & & 0.29 & & 0.44 & & 0.21 \\
\hline
\end{tabular}

Tabel 8. Perbedaan komposisi gulma pada 4 MSA(\%)

\begin{tabular}{lccccccc}
\hline \multicolumn{1}{c}{ Perlakuan } & \multicolumn{7}{c}{4 MSA } \\
\cline { 2 - 8 } Dosis & & $375 \mathrm{~g} / \mathrm{ha}$ & $500 \mathrm{~g} / \mathrm{ha}$ & $625 \mathrm{~g} / \mathrm{ha}$ & $750 \mathrm{~g} / \mathrm{ha}$ & Mekanis & Kontrol \\
\hline $375 \mathrm{~g} / \mathrm{ha}$ & 1 & 0 & 43 & 43 & 50 & 46 & 51 \\
$500 \mathrm{~g} / \mathrm{ha}$ & 2 & & 0 & 38 & 79 & 55 & 23 \\
$625 \mathrm{~g} / \mathrm{ha}$ & 3 & & & 0 & 36 & 63 & 48 \\
$750 \mathrm{~g} / \mathrm{ha}$ & 4 & & & 0 & 63 & 49 \\
Mekanis & 5 & 6 & & & & 0 & 76 \\
Kontrol & & & & & & 0 \\
\hline
\end{tabular}

Tabel 9. Perbedaan komposisi gulma pada 8 MSA(\%)

\begin{tabular}{lccccccc}
\hline \multicolumn{1}{c}{ Perlakuan } & \multicolumn{9}{c}{$8 \mathrm{MSA}$} \\
\cline { 2 - 8 } Dosis & & $375 \mathrm{~g} / \mathrm{ha}$ & $500 \mathrm{~g} / \mathrm{ha}$ & $625 \mathrm{~g} /$ ha & $750 \mathrm{~g} /$ ha & Mekanis & Kontrol \\
\hline $375 \mathrm{~g} / \mathrm{ha}$ & 1 & 0 & 41 & 41 & 22 & 29 & 41 \\
$500 \mathrm{~g} / \mathrm{ha}$ & 2 & & 0 & 38 & 26 & 46 & 46 \\
$625 \mathrm{~g} / \mathrm{ha}$ & 3 & & 0 & 29 & 41 & 26 \\
$750 \mathrm{~g} / \mathrm{ha}$ & 4 & & & & & 0 & 23 \\
Mekanis & 5 & 6 & & & & & 0 \\
Kontrol & & & & & & & 0 \\
\hline
\end{tabular}

gulma yang rendah sebesar 23\%. Gulma yang mendominasi pada petak percobaan 4 MSA adalah O. nodosa, P. clematidea, A. gangetica, Erigeron sumatrensis dan Paspalum comersonii.

Pada 8 MSA terdapat 12 spesies gulma pada petak percobaan. Pada petak percobaan ditemukan perbedaan komposisi gulma dengan nilai sebesar $22-$ $46 \%$ yang ditunjukkan pada Tabel 9 . Pada taraf dosis
$375 \mathrm{~g} /$ ha dan $750 \mathrm{~g} /$ ha memiliki perbedaan komposisi gulma yang rendah sebesar $22 \%$, pada petak percobaan dosis $750 \mathrm{~g} / \mathrm{ha}$ dan penyiangan mekanis memiliki perbedaan komposisi gulma sebesar $18 \%$ dan pada dosis $750 \mathrm{~g} / \mathrm{ha}$ dengan kontrol menunjukkan perbedaan komposisi gulma sebesar $23 \%$.

Pada 12 MSA terdapat 16 spesies gulma pada petak percobaan. Tabel 10 menunjukkan bahwa 
Tabel 10. Perbedaan komposisi gulma pada 12 MSA(\%)

\begin{tabular}{lccccccc}
\hline \multicolumn{1}{c}{ Perlakuan } & \multicolumn{7}{c}{$12 \mathrm{MSA}$} \\
\cline { 2 - 8 } Dosis & & $375 \mathrm{~g} / \mathrm{ha}$ & $500 \mathrm{~g} / \mathrm{ha}$ & $625 \mathrm{~g} / \mathrm{ha}$ & $750 \mathrm{~g} / \mathrm{ha}$ & Mekanis & Kontrol \\
\hline $375 \mathrm{~g} / \mathrm{ha}$ & 1 & 0 & 35 & 45 & 51 & 48 & 45 \\
$500 \mathrm{~g} / \mathrm{ha}$ & 2 & & 0 & 38 & 42 & 54 & 36 \\
$625 \mathrm{~g} / \mathrm{ha}$ & 3 & & & 0 & 56 & 40 & 36 \\
$750 \mathrm{~g} / \mathrm{ha}$ & 4 & & & & 0 & 51 & 55 \\
Mekanis & 5 & & & & & 0 & 36 \\
Kontrol & 6 & & & & & 0 \\
\hline
\end{tabular}

seluruh taraf dosis 375 - $750 \mathrm{~g} /$ ha pada petak percobaan ditemukan perbedaan komposisi gulma dengan nilai sebesar $35-56 \%$. Terjadinya perbedaan komposisi gulma diakibatkan metode pengendalian yang diterapkan untuk mengendalikan gulma tersebut.

\section{Fitotoksisitas Tanaman Kelapa Sawit}

Pengamatan fitotoksisitas pada tanaman kelapa sawit yang pada piringan telah diaplikasikan herbsisida parakuat diklorida taraf dosis $375-750 \mathrm{~g} /$ ha tidak menunjukkan gejala keracunan pada tanaman kelapa sawit belum menghasilkan. Pengamatan tingkat keracunan disesuaikan dengan acuan aturan dari Direktorat Pupuk dan Pestisida (2012) dalam metode standar pengujian efikasi herbisida. Hal ini ditunjukkan dengan tidak adanya perubahan bentuk maupun warna daun pada tanaman kelapa sawit.

\section{KESIMPULAN}

Kesimpulan yang diperoleh dari penelitian ini adalah :

1. Herbsida parakuat diklorida dosis $375-750 \mathrm{~g} / \mathrm{ha}$ efektifmengendalikan gulma total, gulma daun lebar sampai $8 \mathrm{MSA}$, gulma rumput dan gulma teki sampai 4 MSA.

2. Herbsida parakuat diklorida dosis $375-750 \mathrm{~g} / \mathrm{ha}$ efektif mengendalikan gulma Praxelis clematidea sampai 8 MSA, gulma Ottochloa nodosa dan Asystasia gangetica sampai 4 MSA.

3. Herbisida parakuat diklorida taraf dosis $375-750$ g/ha mengakibatkan terjadinya perbedaan komposisi gulma pada 4, 8, dan 12 MSA.

4. Dosis herbisida parakuat diklorida 375 - $750 \mathrm{~g} / \mathrm{ha}$ yang dipalikasikan di piringan tidak meracuni tanaman kelapa sawit belum menghasilkan.

\section{DAFTAR PUSTAKA}

Direktorat Pupuk dan Pestisida. 2012. Metode Standar Pengujian Efikasi Herbisida. Direktorat Sarana dan Prasarana Pertanian. Jakarta. $229 \mathrm{hlm}$.

Hakim. 2007. Kelapa Sawit, Teknis Agronomis Dan Manajemennya. Lembaga Pupuk Indonesia. Jakarta. $295 \mathrm{hlm}$.

Lubis, A.U. 2008. Kelapa Sawit (Elaeis guineensis Jacq.) di Indonesia. Pusat Perkebunan Marihat. Bandar Kuala. Pematang Siantar. 362 hlm.

Murti, D.A., N. Sriyani dan S.D. Utomo. 2016. Efikasi herbisida parakuat diklorida terhadap gulma umum pada tanaman ubi kayu (Manihot 
esculenta Crantz.). J. Agrotek Tropika 1(1):710.

Riry, J. 2006. Daya Saing Tanaman Kedelai Hasil Desikasi Herbisida Parakuat dan Glifosat Terhadap Cekaman Gulma. J.Agrista 10(1): 21-26.

Sembodo, D.R. J. 2010. Gulma dan Pengelolaanya. Graha Ilmu. Yogyakarta. $166 \mathrm{hlm}$.
Setyawibawa, I. dan Y. E. Widyastuti. 1999. Kelapa Sawit Usaha Budidaya, Pemanfaatan Hasil, dan Aspek Pemasaran. Penebar swadaya. Jakarta. $218 \mathrm{hlm}$.

Sukman, Y., dan Yakup. 1995. Gulma dan Teknik Pengendaliannya. CV Rajawali Press. Jakarta. $240 \mathrm{hlm}$.

Suntres, Z.E. 2002. Role of antioxidants in paraquat toxicity. Toxicology. 180(1):65"77. 